\title{
ZNF350 wt Allele
}

National Cancer Institute

\section{Source}

National Cancer Institute. ZNF350 wt Allele. NCI Thesaurus. Code C98159.

Human ZNF350 wild-type allele is located in the vicinity of 19q13.4 and is approximately $160 \mathrm{~kb}$ in length. This allele, which encodes zinc finger protein 350, plays a role in the negative regulation of transcription. 